\title{
Urbes industrializada: o modernismo e a paulicéia como ícone da brasilidade
}

\author{
Maria Inez Machado Borges Pinto
}

Universidade de São Paulo

\section{RESUMO}

Este artigo tem como objetivo analisar a participação da intelligentsia paulistana na configuração do regionalismo em São Paulo. 0 caráter contraditório da relação entre nacionalismo/regionalismo. 0 artigo tenta acompanhar essas questões ao longo da década de 1920, através do exame da obra de Mário de Andrade, em que as contradições apontadas afloram, bem como as vozes dissonantes de Antônio de Alcântara Machado, Manuel Bandeira, ou de cronistas obscuros, que se colocaram à margem da tensão cosmopolitismo nacionalismo/regionalismo.

Palavras-chave: modernismo; urbanização; São Paulo.

\section{ABSTRACT}

This article intends to analyse the participation of the paulista's intelligentsia in the configuration of the regionalism in São Paulo. The contraditory character of relation between nacionalism and regionalism. The article searches to attend these questions all long of the twenty years, through Mário de Andrade's works, where those contradictions appearing, how as well as a dissonant voices of the authors like Antônio de Alcântara Machado, Manuel Bandeira or obscurity chroniclers which put themselves in the edge of the tension cosmopolitism - nacionalism/regionalism.

Keywords: modernism; urbanization; São Paulo.

A proximidade das comemorações do centenário da Independência em 1922 fizeram aflorar, para a intelligentsia brasileira, a necessidade de não apenas repensar os rumos da República, mas também de traçar para o País novos caminhos a ser trilhados. No Brasil, a intelectualidade comprometida com a construção de um Brasil moderno oscila entre tradição e vanguarda.

Uma corrente buscava sintonizar a realidade nacional com o ritmo veloz e febril do novo mundo urbano e industrial; outra, igualmente filiada a correntes internacionais, de caráter conservador, marcada pelo apelo aos valores da natureza e do campo, pelo repúdio ao industrialismo e à modalidade da vida urbana, litoralista, cosmopolita e liberal. Ambas se unem pela oposição às preten- 
sões da razão universal derrotada na guerra e advogam a originalidade de cada nação.

0 artificialismo que permeava toda a estrutura brasileira teria atingido em cheio a intelectualidade, especialmente a litoral-cosmopolita. Machado de Assis, criticado por seu "cosmopolitismo dissolvente", de um lado, e Euclides da Cunha, ligado à "força da terra", de outro, representariam parâmetros da atividade intelectual balizados numa dicotomia que relacionava sertão/brasilidade e lito$\mathrm{ral} /$ cosmopolitismo.

Bastante conservadora, impregnada do modelo do realismo/naturalismo, enfocando o homem "rude" do sertão com ingênuos arroubos românticos idealizadores do interiorano e da paisagem que o envolve, essa literatura sertanistacabocla voltou-se também para a exaltação dos mitos paulistas, especialmente o bandeirante, entronizado como verdadeiro herói nacional.

Em contrapartida, os intelectuais ligados ao modernismo, em que pese 0 fato de também criticarem o Rio de Janeiro e buscarem um novo nacionalismo, não o encontrariam no campo, mas sim, através da industrialização e da urbanização, da completa interligação com os fluxos irresistíveis da modernidade. Para autores como Mário de Andrade, Oswald de Andrade, Menotti del Picchia e

436 Guilherme de Almeida a busca de uma nova nação passava necessariamente pela "oposição ao passadismo, a busca da atualização e modernização cultural, em sintonia com as vanguardas européias", além da adesão aos novos ritmos da vida urbana. A cidade de São Paulo com seu dinamismo, suas fábricas, seu progresso, espírito pragmático, sua realidade urbano-industrial, a incorporação das novas tecnologias da sociedade de massas e a imigração européia representava a base "para superação do atraso e garantia da entrada do país na modernidade".

Para esse expressivo grupo de intelectuais, especialmente aqueles que dentro do modernismo admiravam os cânones vanguardistas - Mário de Andrade, Oswald de Andrade, Menotti del Picchia, Guilherme de Almeida, dentre outros - era difícil acreditar que o Brasil estava no sertão...Essa identidade é indissociável da idéia de modernidade, quando

a vida multiforme e absorvente, maravilhosa na sua complexidade, violenta na sua tragédia e na sua vertigem, a vida no século XX, com fábricas e bolchevismo, com o sangue ainda quente derramado no holocausto da grande guerra, pede outra técnica para a sua representação, outra expressão verbal (.... $)^{1}$

Sintomaticamente é a partir dessa época que começam a surgir os estereótipos sobre os habitantes das várias regiões do País; assim, o carioca passa a ser 
caracterizado pelo seu jeito boêmio e malandro, em contraposição ao paulista, que é disciplinado e trabalhador, e ao mineiro, moderado e austero. Por trás dessas construções estava a tentativa de se determinar qual região iria comandar a nação. Os modernistas paulistas tiveram um papel proeminente na formulação desse regionalismo, procurando legitimar São Paulo como líder da nação em detrimento do Rio de Janeiro. Para esses autores, São Paulo encarnava uma dupla face de tradição e vanguarda, pois era habitada por todos os tipos de povos e, berço dos bandeirantes, era voltada para o interior; além disso, a cidade estaria melhor preparada para se inserir na modernidade do século XX.

A questão regional, tal como era posta, recobria um sério debate: qual seria a região capaz de impor seu tom ao conjunto nacional? Que características a capacitavam a exercer o papel de matriz da nacionalidade? Determinados aspectos geográficos, certas tradições históricas e o "caráter" do seu povo eram, sem dúvida, os trunfos mais valorizados.

Modernistas de São Paulo como: Mário de Andrade, Oswald de Andrade, Menotti del Picchia, Guilherme de Almeida, Plínio Salgado, para citar os mais destacados - também participaram ativamente da configuração do regionalismo paulista. Um dos pilares desse regionalismo foi a legitimação da metrópole bandeirante como cabeça da nova nação que então buscava construir, implicando a desqualificação do Rio de Janeiro para exercer este tradicional papel.

O coração do Brasil brasileiro e moderno seria São Paulo. Metrópole 'febril', industrializada, habitada por todos os tipos de raças e de povos, nem por isso desapegara-se dos sólidos valores da brasilidade. Voltada para o interior, berço do bandeirante, a urbe paulista não apresentava o artificialismo característico das cidades litorâneas - com seu cosmopolitismo dissolvente; ao contrário, impregnara-se dos princípios 'verdadeiros' do meio rural. Dessa maneira, São Paulo conseguiria encarnar a modernidade do pós-guerra na sua dupla face, a da tradição e da vanguarda; nenhuma outra cidade sintetizaria melhor os valores da brasilidade e da modernidade. Em termos poéticos, incorporando à estrutura intrínseca do poema recursos narrativos da cinemática descritiva, similar aos procedimentos do futurismo italiano, Oswald de Andrade, através da visualização de uma estrutura dinâmica capta o movimento frenético e contraditório da urbanização híbrida de São Paulo, com seus traços provincianos, rotineiros, e aquela mútua avidez "futurista" pelo progresso: 
Locomotivas e bichos nacionais

(...)

A verdura no azul Klaxon

(...)

Arranha-céus

Fordes

Viadutos

Um cheiro de café.

$(1925)^{2}$

No que diz respeito ao campo cultural, a Semana de Arte Moderna realizada na capital paulista, em fevereiro de 1922, trazia explicitamente a mensagem de abolir a "República Velha das Letras", claramente identificada com o Rio belle époque. Para os modernistas paulistas, a "nova" cultura brasileira precisava se fixar no solo sólido de uma cidade "moderna", capital do Estado mais desenvolvido da federação. Em suma, era preciso garantir para a "febricitante" São Paulo o lugar de principal pólo industrial do País, de centro das decisões no concerto político nacional e de eixo da produção cultural brasileira moderna.

A prosperidade econômica do Estado de São Paulo refletia nas rápidas transformações que se operavam no cotidiano da sua capital, com as chaminés e os arranha-céus despontando aqui e ali; precisava ter uma correspondência no campo cultural. Cumpria, pois, firmar ao lado da fama de povo "rico, forte e generoso", o lugar de São Paulo como fonte das mais “desassombradas” expressões de autonomia intelectual e de "notável” produção literária e artística; contra o estereótipo de cidade material, argentária, pois São Paulo era "com suas fábricas, com sua riqueza (...), o sonho de todos aqueles que tragam quer um ideal de arte, quer um ideal realizador de trabalho".

0 movimento editorial é o indicador constantemente apontado para ressaltar a relevância cultural da capital bandeirante. Inevitáveis paralelos são traçados com o Rio de Janeiro, matriz até então incontestável da produção intelectual do País.

Ao contrário do ideal romântico do intelectual contemplativo bem ao gosto da "camelote acadêmica", São Paulo tem a oferecer o braço que trabalha e o cérebro que cria. É a "incude e o pensamento; Hércules e Apolo"; ação e criação. A legenda bandeirante "Non ducor, duco" deve-se afirmar em todos os campos de atividade, econômica, política e cultural.

Na avaliação de Mário de Andrade,

São Paulo estava mais 'ao par' que o Rio de Janeiro. E socialmente falando, o mo- 
dernismo só podia mesmo ser importado por São Paulo... São Paulo era muito mais moderna, porém, fruto necessário da economia do café e do industrialismo conseqüente....São Paulo estava ao mesmo tempo, pela sua atualidade comercial e sua industrialização, em contato mais espiritual e mais técnico com a atualidade do mundo...É mesmo de assombrar como o Rio mantém, dentro da sua malícia vibrátil de cidade internacional, uma espécie de ruralismo, um caráter parado tradicional muito maiores que São Paulo. ${ }^{5}$

Ao definir a cidade de São Paulo como berço do modernismo porque era "espiritualmente muito mais moderna", o autor da Paulicéia Desvairada conclui que no Rio, a "grande camelote acadêmica", "sorriso da sociedade", "corte imperialista”, seria impossível a eclosão desse movimento devido ao seu atraso cultural. 0 exotismo folclórico do samba, a falta de um espírito aristocrático negavam à capital federal o espaço da modernidade já ocupado pela metrópole bandeirante.

Para essa linha de interpretação converge a avaliação de Antônio Cândido, para quem o modernismo, tal como o romantismo, seria um "momento paulistano", quando a capital bandeirante se projetara sobre a nação buscando "dar estilo às aspirações do país todo."

Através de seus intelectuais, principalmente os modernistas, a capital paulista pretendia alcançar a liderança cultural, reivindicando para si a direção da inteligência brasileira. Filiados a agremiações político-partidárias, articulistas de jornais claramente identificados com essas agremiações, membros da administração pública estadual, impregnados de um forte sentimento de paulistanidade entendida na sua dimensão identificadora, esses intelectuais associariam às tarefas políticas as lutas no campo artístico-literário.

Temos aqui, diante dessa análise, uma das contradições dos modernistas de São Paulo, pois se de um lado rejeitavam todos os outros regionalismos tachando-os de passadistas e anti-modernos, por outro lado queriam colocar no lugar um novo regionalismo, só que este de matriz paulista.

Vale a pena salientar uma mudança de atitude de boa parte dos autores modernistas com relação ao nacionalismo, fato que, segundo Eduardo Morais, vai estar diretamente relacionado com os acontecimentos da Revolução Paulista de 1924, originados na onda crescente do tenentismo.

Essa insurreição militar teve início do dia 5 de julho de 1924, quando os revoltosos tomaram os quartéis do exército, força pública, estações de trem, bem como grande parte da área urbana da cidade. 0 presidente do Estado, Carlos de Campos, retirou-se da cidade ordenando um bombardeamento indiscriminado, pois era incapaz de detectar a posição dos revoltosos. Dessa forma, a capital foi sistematicamente alvejada, sendo especialmente visados os bairros operários e 
populosos, embora não escapassem também escolas, hospitais e igrejas. Passados 29 dias, o general dos revoltosos solicitou uma trégua, mas só obteve como resposta de Carlos de Campos a rendição incondicional ou a destruição completa da cidade. Diante disso, os rebeldes decidiram abandonar a cidade, partindo de trem no dia 27 de julho em direção a Foz do Iguaçu, unindo-se aos tenentes gaúchos, fato que marcou o início da Coluna Prestes, sob o comando do tenente Luís Carlos Prestes. As forças legais reocuparam a cidade com uma brutalidade inaudita, saqueando, espancando, prendendo populares julgados colaboracionistas, além de executarem sumariamente grupos inteiros de imigrantes suspeitos de terem aderido à revolta.

Assim, se no primeiro momento modernista a preocupação era combater o passado em nome da atualização/modernização, a partir de 1924 ocorreu uma mudança de perspectiva, ou seja, colocou-se a óptica do nacionalismo como processo de renovação: "só seremos modernos se formos nacionais". Neste sentido, o "Manifesto Pau-Brasil", de Oswald de Andrade, lançado em 1924, pode ser considerado uma obra inaugural. Aqui "não é o passado genérico que é negado, mas parte concreta deste passado, o lado bacharelesco, aquele que escondia, em função do processo de transplantação cultural, o verdadeiro passado brasileiro que deveria ganhar visibilidade. Por esta razão também a importância do contato com as vanguardas européias é menos decisiva que no primeiro tempo modernista. Nosso material cultural deve ser descoberto aqui mesmo."

No entanto, a contradição regionalismo / nacionalismo persistiu após 1924, como pode ser percebido pelo debate entre Sérgio Milliet e Mário de Andrade, ocorrido em 1926, nas páginas da revista Terra roxa e outras terras. Milliet, no primeiro número do periódico, comenta um livro de poemas de Guilherme de Almeida, afirmando que a qualidade da obra se devia ao seu teor de brasilidade; o problema era confundir essa brasilidade com paulistanismo. Mário de Andrade responde aos comentários de Milliet no número seguinte, na forma de uma "carta-protesto":

Sérgio Milliet. Estou ficando o homem das cartas...Porém, a culpa é de você. Que historiada é essa, Sérgio, meu amigo, de falar, na sua crônica sobre poesia do número passado, que 'só se é brasileiro sendo paulista!' Protesto. É pena que já não tenha saído o número 4 da revista Estética porque lá eu verifico que vou perdendo cada vez mais e completamente a noção dos limites estaduais...Em que sentido simbólico heróico grandiloqüente errado você está empregando a palavra 'paulista!' Eu não nego um valor enorme sobretudo no passado dos meus coestaduanos, porém carece tomar cuidado com os símbolos e com os sentimentos perniciosos. Como o símbolo, o paulista é também aquela besta reverendíssima da guerra dos Emboabas, ainda por cima arara e covardão.... E é ainda o homem...bom, inda é 
cedo para comentar o procedimento dos paulistas durante a Isidora e a gente vive em estado de sítio. Porém eu, que vivi na rua observando revoltosos e legalistas, tenho muito que contar sobre a psicologia do paulista.

E a nossa riqueza e progresso atuais, você já reparou como eles nascem do acaso, de circunstâncias climáticas e geológicas? Você já meditou naquelas frases verdadeiras da Paulística de Paulo Prado sobre a decadência do caráter paulista?

Você e outros me chamam de sentimental e de romântico porque gosto de gemer no verso e no pinho o amor melado e caricioso do brasileiro e porque o grito o 'Vem minha gente' pros brasileiros sem limites estaduais da nossa terra. Pois me parece, Sérgio companheiro, que o sentimentalismo não está em gemer, gozando os desejos que nascem no corpo e no espírito, porém em se deixar levar por vaidadinhas rompantes e afirmativas ser realidade e perigosas. Perigosa como a de você que é desnacionalizante e irritante e errada. 0 Brasil é um vasto hospital. Amarelão de regionalismo e bairrismo histérico. Visão de míope sem futuro e sem presente. Cuidado com o saudosismo! É sintoma de decadência. Sérgio, você errou, Sérgio. Te abraço, Mário de Andrade. ${ }^{8}$

Tem-se assim um aspecto não resolvido dentro do movimento modernista. 0 próprio Mário de Andrade vai, segundo Eduardo Moraes, incorrer em contradições, uma vez que, ao criticar o regionalismo de Milliet, toma a mesma posição do criticado - pelo lado diferente da mesma moeda - , quer dizer, vai ressaltar os aspectos negativos dos paulistas ao contrário das posições bairristas e ufanistas. "A maneira de pensar, no entanto, é a mesma...seus propósitos são nacionalistas, mas seu fundo revela os traços de arraigado 'paulistanismo."'"

"A tensão nacionalismo / bairrismo se configura como um conflito inconsciente que se manifesta na área de seu conflito consciente: pátria / internacionalidade. 0 escritor consegue aceitar plenamente a segunda oposição, uma vez que tem pátria como fator de nacionalidade capaz de proporcionar no futuro a internacionalidade na área política e a universalidade na área estética. Entende pátria como necessidade histórica, capaz de despertar a consciência nacional e fundamentar uma cultura brasileira autêntica.

Pátria é o nacionalismo que não pode admitir o Regionalismo estético e político, pois ele fragmentaria a sua coesão. Apesar de negá-lo, Mário de Andrade não percebe quando mergulha em profundidade na área do particular, sobrepondo inconscientemente um estado à região e à totalidade da nação. Tornando-se bairrista ao valorizar excessivamente São Paulo, em detrimento do conceito que manifesta sobre os outros estados, mormente os do Norte. Essa é entretanto uma posição sua que o afeta exclusivamente nos aspectos ideológicos. Deve ser analisada dentro de sua ligação com o nacionalismo porque auxilia a compreensão dos compro- 
missos políticos que assume e de algumas interpretações suas sobre a literatura popular."10

Diante desse panorama, acreditamos ser relevante empreendermos uma análise mais acurada da obra de Mário de Andrade, visando a aprofundar as questões apontadas até aqui.

Há na obra poética de Mário de Andrade um ponto de partida a que volta, no fim da existência, após uma longa viagem de descobertas e encantamentos. É de São Paulo e do amor a São Paulo que ele parte para o amor ao Brasil. Através deste se engrandece aquele no amadurecimento de seus cinqüenta anos. 0 poeta paulistano nasce bairrista como todo paulista que se respeita, e São Paulo lhe parece, desde logo, numa visão análoga ao provincianismo apologético e ufanista de seus contemporâneos, o grande acontecimento do mundo.

0 primeiro verso de seu primeiro livro o afirma cheio de terno orgulho, mergulhado numa perspectiva de profunda admiração pelo processo de urbanização eufórico da "cosmópolis":

São Paulo, comoção de minha vida!

Paulicéia Desvairada é um canto à magia de sua cidade, que passava pelo processo de formação de uma sociedade urbana complexa e multidiferenciada, nesta obra, o autor já ressalta o fenômeno cultural peculiar que a cidade representa como guia e símbolo da nova cultura nacional. Paulicéia Desvairada, símbolo da nova cultura nacional, escrito em 1921, é a oportunidade de casar seus anseios estéticos de dinamismo na poesia com a lição recebida dos unanimistas e dos futuristas. Com efeito, em Jules Romains encontrara a apresentação da dinâmica de uma cidade como forma de coletivização, já mostrando a máquina, 0 veículo. Mas Romains e Verhaeren, de Villes tentaculaires, trazem o assunto cidade com um sentido geral, amplo, particularizado por Mário como a cidade de São Paulo, com a qual se sentia afetivamente ligado. Na poesia disseca liricamente a sua cidade.

Dentro desse mesmo espírito, era fácil entender porque, na concepção otimista de Mário de Andrade, a sede da civilização mameluca dos bandeirantes era não só o foco da história do País desde os tempos coloniais, como ainda a fonte com a sua sociedade florescente e o seu cosmopolitismo progressista de todas as melhores expectativas para a sociedade nacional rumo ao futuro.

Nele, a manifestação de bairrismo é de 1925 e está relacionada com a divulgação das idéias do Modernismo. Discute Pau Brasil de Oswald de Andrade e camufla seu bairrismo, estendendo a caracterização estadual feita pelo autor para a amplitude nacional, quando trata da apropriação da "Canção do exílio" de 
Gonçalves Dias pelo poeta. Mas, logo depois, passa a explicar seus próprios sentimentos.

Não permita Deus que eu morra

Sem que volte pra São Paulo

Sem que veja a rua Quinze

E o progresso de São Paulo"

\section{(...) é gostosíssimo! Vocês mudem 'S.}

Paulo' pra Porto Alegre, Natal, Rio Branco e hão de se sentir o mesmo que eu. Pensem não que sou bairrista! Me sinto cada vez mais incapaz de ser do meu Estado. Perdi completamente a noção dos limites estaduais. Adoro minha Paulicéia e sou indivíduo do Brasil. Mas que gosto da rua Quinze, isso gosto deslumbradamente. ${ }^{11}$

Nega bairrismo a propósito de nada, exatamente quando acabava de ampliar o alcance dos versos de Oswald. Como se trata de seu primeiro depoimento sobre 0 assunto, pode-se pensar desavisadamente que o escritor se livrara de uma possível pecha que lhe seria atribuída pelo apego ao seu tema principal, São Paulo.

No ano seguinte, contudo, 1926, o bairrismo fica melhor caracterizado. Defende os modernistas de São Paulo da acusação de Tristão de Athayde de que seriam "primitivos" por imitação dos franceses, que consideravam o espetáculo circense como manifestação de profundo interesse estético. Afirma então que São Paulo apresenta grau de cultura mais elevado que o Rio de Janeiro, e escreve:

(...) Juro: meu interesse não é porque São Paulo tenha cultura, porém que o Brasil seja um corpo bem igualado. Até às vezes me ponho imaginando que o progresso de São Paulo é um mal pro Brasil, porque faz desta nossa terra harpiforme um desequilíbrio espandongado e anormal.

(...) Não tenho culpa de Navarro da Costa não ser comprado no Rio onde os novos-ricos portugas são tão numerosos como os novos-ricos sírios e italianos de São Paulo, e por ser compradíssimo por aqui... pela gente bem paulista mesmo, famílias bem tradicionais e de riqueza às vezes secular. Também tem riquezas seculares no Rio. De tudo isso culpa não é minha, porém, depois que dei para orador pé-de-boi, falo mesmo o que tenho de falar. E ali, no duro! ${ }^{12}$

Mais uma vez se furta ao rótulo de bairrista, apesar de agir como tal, brigando pelo que julga direito de São Paulo. 
No poema magistral "Tu", o poeta reflete o seu deslumbramento para com a paisagem, inacabada, indefinível e contraditória da cidade, misto de arcaísmos, aspectos roceiros e modernidade, "mulher feita de asfalto e de lamas de várzea", graciosa, juvenil e arrivista, com ares provincianos e cosmopolitas, "risco de aeroplano entre Mogi e Paris", meio-fidalga, meio barreguã", "costureirinhas de São Paulo", ítalo... bandeirantemente alucinadas com as torres de São Bento, pronunciando à utopia da grandiosa metrópole dinâmica no seu vir-aser, híbrida junção de multietnias: "desbravadores coloniais" e "aspiração londrina", "materialização da Canaã do meu Poe".

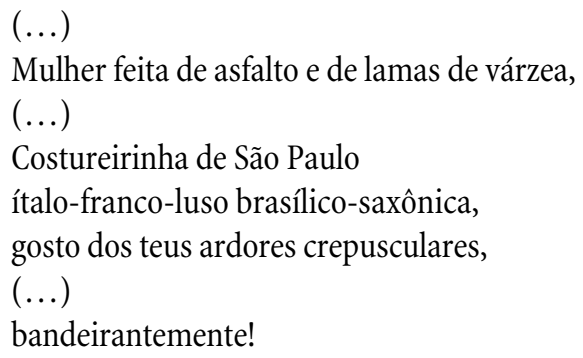

Lady Macbeth de névoa fina, (...)

Trituração ascensional dos meus sentidos! Risco de aeroplano entre Mogi e Paris! ${ }^{13}$

O amor pela cidade é tão amplo que Mário de Andrade demonstra complacência e compreensão para com o consumo popular massificado de notícias criminais, o gosto folhetinesco e nada erudito "de crime turco", um dos traços mais peculiares da nova cultura urbana, que se formava, assim como para com a avidez desenfreada por negócios e lucros, uma das marcas emblemáticas da cidade emergente e argentária da belle époque.

É tão cego esse amor e a fé otimista na missão irradiante e regeneradora da cidade, que os maiores defeitos da sua terra lhe parecem admiráveis qualidades. E mesmo quando não pode negar o erro o poeta sofisma, e com a insensatez dos amantes apaixonados prefere mudar o ângulo de apreciação. Assim, o próprio clima instável, úmido e enfermiço da Paulicéia lhe inspira versos de encanto. A neblina perde o seu aspecto malfazejo. Não é mais o que resfria, é o que torna São Paulo semelhante aos ares mundanos da cosmopolita Londres:

Minha Londres das neblinas frias!

Pleno verão. Os dez mil milhões de rosas paulistanas! (1922) 
E até a ironia e o viés crítico com que atacava os pruridos de nobreza dos ricos da cidade, salientando o arrivismo sôfrego da nova burguesia paulistana, ávida por dinheiro, bens materiais, ambição desmedida pelo lucro econômico, desfaz-se mansamente ao sentir a lenta descida da neblina sobre o bairro elegante e chic, símbolo do novo mundanismo da capital irradiante:

Higienópolis...

Casas nobres de estilo...Enriqueceres em tragédias...

Mas a noite é toda um véu-de-noiva ao luar. (1922) ${ }^{14}$

E que mais ama mais ele na sua cidade? As rosas e os arranha-céus, o imigrante e os crepúsculos e as tardes de abril. As rosas retomam a cada instante na sua poesia como um estribilho, exprimindo a admiração do poeta com a remodelação urbana da cidade e o aburguesamento dos espaços públicos com a construção dos belos jardins e bulevares da belle époque. Em "Paulicéia Desvairada", elas aparecem logo nos primeiros versos: "Pleno verão. Os dez milhões de rosas paulistanas."

De todos esses amores, o amor ao imigrante é o que parece ter passado mais depressa. E para não voltar. Sinal dos tempos? Os nacionalismos desvairados andaram por aqui, como por toda parte, e se não chegaram a contaminar o profundo espírito humanístico de Mário de Andrade, pelo menos extinguiram uma fonte na imaginação criadora do poeta.

0 carinho e a valorização do filho de italiano, como o novo cidadão paulista operoso e progressista, que foi também característico de outros escritores paulistas, principalmente Antônio de Alcântara Machado, morreu prematuramente com "Paulicéia". 0 imigrante italiano, visto como condutor do progresso e da industrialização, é elemento positivo, como mostrara no poema "O domador", não sem uma certa dose de nostalgia.

Neste livro é que se fala com emocionante orgulho de um:
(...)
heróico sucessor da raça heril dos bandeirantes, um galhardo filho de imigrante loiramente domando um automóvel..$^{15}$

E na mesma obra é que se registra o burburinho ensurdecedor e o movimento ruidoso dos pregões do pequeno comércio clandestino de gêneros de primeira necessidade e a prestação de pequenos serviços pelas ruas da cidade, dando visibilidade a uma urbanização mais afeita a uma economia de pequenos ganhos - informal, e menos centrada nos grandes negócios da empresa cafeei- 
ra. Documentou com originalidade e concretude as características locais de um trabalho grosso modo instável e temporário, a sobreviver nas fímbrias das elites europeizantes do café, através da fala ítalo-paulistana dos vendedores ambulantes.

Quanto aos arranha-céus serão eles, segundo Sérgio Milliet, aquilo que mais agrada e sensivelmente forneceu imagens a Mário de Andrade, exprimindo o seu entusiasmo e euforia exagerada com a cidade que se verticalizava, assim, deparamos no poema "Improviso do mal da América":

Lá fora o corpo de São Paulo escorre vida ao guampaço dos arranha-céus $(\ldots)^{16}$

Também no "Poema da amiga", a visão mítica da cidade vertical, concebida como "estrutura americana" - não apenas por sua extensão gigantesca, mas por sua inserção futurista na geografia cosmopolita da "urbes dos arranha-céus" —, explicita a visão apaixonada e heróica do autor pela metropolização febril, milionária e "imprevistamente enorme da cidade":

A tarde deitava nos meus olhos

E a fuga da hora me entregava abril,

Um sabor familiar de até logo criava (...)

Estavas longe, doce amiga; e só vi no perfil da cidade

0 arcanjo forte do arranha-céu cor-de-rosa

Mexendo asas azuis dentro da tarde. $(1930)^{17}$

Nem sempre essa imagem da metropolização frenética da cidade "andares sobre andares" é de orgulho. Em "Momento" no "Grão Cão de Outubro", ela é quase de desespero, de pavor com a solidão, imagem do poeta isolado num mundo hostil e que tenta em vão apegar-se a qualquer coisa, aconchegar-se a um calor:

As pombas se agarram nos arranha-céus, faz chuva

Faz frio. E faz angústia $(\ldots)^{18}$

Na sua "Paulicéia Desvairada" muitos dos seus poemas primavam pela ironia, ora fina, ora beirando o sarcasmo, com a qual fustigava algumas das mais torpes fontes do mal-estar endêmico e ar enfermiço da cidade com seus batalhões de trabalhadores desempregados e semi-ocupados. Na cidade de São Paulo, o quanto se tornava mais chocante, visto que a miséria geral da população contrastava de forma constrangedora com os símbolos da modernidade e rique- 
za: avenidas remodeladas, automóveis, palacetes, a ganância do dinheiro, 0 aventureirismo e o cinismo dos processos para se obter bens materiais. Travestido de arlequim, o poeta musicava seu verso, agitava o ritmo e, num clima de animação eufórica sem tirar a máscara evocava as vítimas, a fragmentação e o caos social, criticando o "canibalismo dos arrivistas".

A crítica à ganância de dinheiro, à simulação, e o cinismo dos processos de enriquecimento rápido da nova burguesia arrivista e multirracial da urbes, composta por nacionais migrantes de vários Estados e imigrantes de diversas procedências de além mar à custa da discriminação social, étnica e da pobreza da população trabalhadora, emerge claramente no poema "Ode ao Burguês":

Fora os que algarismam os amanhãs!

(...)

Morte ao burguês mensal!

Ao burguês cinema! Ao burguês tílburi!

Padaria Suíssa!

(...)(1922) ${ }^{19}$

De fato, o poeta faz notar que apesar do enriquecimento econômico global da "Paulicéia", a participação social no sistema produtivo e na absorção dos recursos gerados era muito limitada, ficando grande parte da população na situação de desemprego, precariedade de trabalho, carência e insalubridade domiciliar. Assim como muito limitada e até decrescente era a participação política. As elites agrárias, beneficiárias e procedentes da tradicional divisão internacional do trabalho, constituíam um sistema oligárquico semi-fechado, que de conformidade com os círculos plutocráticos urbanos, monopolizavam os postos diretivos e as atividades mais rendosas. As oportunidades restritas que o crescimento do sistema oferecia eram alvo de uma rude concorrência pelas amplas camadas urbanizadas, reforçando comportamentos agressivos e desesperados de preconceito e discriminação.

A contingência da crise social e econômica revelam o cenário nebuloso e dramático da modernidade da urbes com a imagem aterradora da "miséria de sobrecasaca e gravata", que vinha se somar à dos "bandos de pés descalços" que circulavam pelo centro reurbanizado, pelas áreas fabris e povoavam os bairros operários.

Eis um exemplo tirado da "Paisagem n⿳0 2": 
(...)

Deus recortou a alma da Paulicéia num cor-de-rosa cinza sem odor... (...)

E rodando num bando nefário, vestidas de eletricidade e gasolina, as doenças jocotoam em redor... (...)

São Paulo é um palco de bailados russos.

Sarabandam a tísica, a ambição, as invejas, os crimes e também as apoteoses da ilusão... (...)

Quá, quá, quá! Vamos dançar os fox-trot da desesperança a rir, a rir dos nosso desiguais! (1922) ${ }^{20}$

Não raro a sátira desvela e ridiculariza a própria ideologia oficial, fazendo desfilar mecanismos de opressão para com a indignação mal contida. A "Paisagem $\mathrm{n}^{\circ} 4$ " conclui o livro com uma frase de deboche, que ressalta o caráter diversionário do empenho de arregimentação do orgulho cívico paulista:

Os caminhões rodando, as carroças rodando, E o largo coro de ouro das sacas de café!... (...)

Mas as ventaneiras da desilusão! A baixa do café!...

As quebras, as ameaças, as audácias superfinas!...

(...)

Lutar!

As bandeiras e os clarins dos armazéns abarrotados...

(...)

Mutismos presidenciais, para trás! $(1922)^{21}$

Mas acontece serem versos de euforia, o que marca a tônica da produção cultural do autor, e aqui vemos na sua melhor moldura mais um dos grandes amores paulistanos de Mário de Andrade: as tardes de abril. E na tarde de sua própria vida, quando escreveu a "Lira Paulistana", para a garoa de sua cidade e para os seus crepúsculos é que se voltará como à procura de um gesto justo e relaxante repouso: "garoa de meu São Paulo / . . . Meu São Paulo da garoa /...Garoa sai de meus olhos".

Entrementes, Mário de Andrade andará por aí, redescobrindo o imenso e multifacetado Brasil, com seus múltiplos regionalismos, a pluralidade da cultu- 
ra de povoado, a diversidade das culturas populares, conhecendo e amando sua terra através do "Noturno Belo Horizonte", do "Carnaval Carioca", das lendas amazônicas, do folclore do Nordeste, da gíria do Rio Grande do Sul. No entanto, Mário de Andrade criará uma "gramatiquinha da fala brasileira"; lançou-se em especial à elaboração e ao emprego de uma linguagem exclusivamente brasileira que deu aos seus romances um tom nativista muito original, escreverá "Macunaíma", se ligará pela sua enorme correspondência a toda uma nova geração de intelectuais, dentre os mais expressivos do País. Toda a sua inteligência e toda a sua sensibilidade estarão a serviço da pátria grande, pois como afirmava no "Manifesto Modernista", "vivíamos já de nossa realidade brasileira, carecia reverenciar o instrumento de trabalho para que expressássemos com identidade". 22

Para Carlos Drummond de Andrade, fica por demais transparente que a poesia modernista foi, em grande parte, uma poesia de região, de município e até de povoado, que se atribui a missão de redescobrir o Brasil, considerado antes encoberto do que revelado pela tradição literária de cunho europeu. Os nomes das pequenas cidades brasileiras figuravam pela primeira vez em verso, a fala do povo incorporou-se à linguagem erudita da poesia "São Brasil!" - exclamava nosso poeta máximo, precisamente no ano da graça de 1925. Mas esse excesso de Brasil corria o risco de degenerar simplesmente em excesso de pitoresco, de tal modo o particular se substituía ao geral, na sofreguidão dos revolucionários, marcados ainda por uma tendência pulverizadora ao humanismo..$^{23}$

No “Clã Jabuti”, publicado em 1927, mas reunindo poesias de 1924, Mário de Andrade assume ainda mais ostensivamente uma tônica de compor símbolos e representações nacionais, fortalecidos pelo aliciante sentido rítmico e a musicalidade vernacular dos seus versos. No longo e complexo poema "Noturno de Belo Horizonte", composto logo após as excursões da "descoberta", pode-se apreciar em especial a construção de uma imagem mítica de Minas Gerais, descendente e fruto paulista, concebida como o epítome símbolo da nação. Desbravada e povoada por paulistas, espaço cosmogônico da epopéia histórica dos bandeirantes, da luta contra a cobiça espúria do estrangeiro invasor, com se viu n’ $O$ Contratador, distante do litoral e incrustada no sertão solidamente associada às raízes, às pedras, minérios, montanhas, às elevações, igrejas e torres, ela representa ao mesmo tempo uma São Paulo da pureza dos velhos tempos e, com a força e a dinâmica da modernidade, algo que já não é São Paulo, mas sua incorporação e coligação com o cerne do corpo da nacionalidade, no centro dos sertões interiores, irradiando o puro espírito autóctone e purificando as interferências e contaminações alienígenas. É particularmente forte a culminância final 
do poema no símbolo litúrgico da água emanando das rochas elevadas, de uma reverberação mítica ilimitada.

(...) Minas Gerais, fruta paulista...

(...)

Frutificou mineira! Taratá!

(...)

Milharais canaviais cafezais insistentes

(...)

Os pratos nativos são índices de nacionalidade.

Mas no Grande Hotel de Belo Horizonte servem à francesa.

(...)

Mãos esqueléticas de máquinas britando minérios,

As estradas-de-ferro estradas-de-rodagem

(...)

Progresso! Civilização!

(...)

O morfético ao lado da estrada esperando automóveis...

(..)

Portugal reuniu 22 orquídeas desiguais.

(...)

Nós sabemos os brasileiros auriverdes!

(...)

Que importa que uns falem mole descansado

Que os cariocas arranhem os erres na garganta

Que os capixabas e paroaras escancarem as vogais?

Que tem si o quinhentos-réis meridional

Vira cinco tostões do Rio pro Norte?

Juntos formamos este assombro de misérias e grandezas,

Brasil, nome de vegetal!...

O bloco fantasiado de histórias mineiras

(...)

É o delírio noturno de Belo Horizonte...

(...)

$(1927)^{24}$

Porventura, a questão que perpassa aquele debate entre Milliet e Mário já esteja para além do confronto entre cosmopolitismo e nacionalismo, tão carac- 
terísticos do período de consolidação da República e que marcaram as comemorações do centenário em 1922. Nesse momento, ocorre um gradativo aumento do maniqueísmo acerca da discussão sobre o nacionalismo. Fatos que parecem sinalizar os abalos estruturais da economia cafeeira. " 0 tom era tão claro e preocupante jacobino, evocando as campanhas xenófobas de desestabilização política do início crítico do período republicano, nesse momento delicado em que já se percebia o abalo estrutural da economia cafeeira, que as autoridades oficiais contra-atacaram, mobilizando-se os escritores ligados aos quadros e jornais do PRP para uma autêntica batalha de manifestos". Neste momento a luta é travada entre um matiz de nacionalismo assimilacionista contra outro intransigente. 0 texto que mais claramente assumia a vertente oficial era o manifesto do verde-amarelo (1929), por trás do qual estavam Cassiano Ricardo, Guilherme de Almeida, Menotti del Picchia e Plínio Salgado 0 manifesto deixa transparente o maniqueísmo que assumira o debate nacionalista, identificando os adversários "intolerantes" com o modelo negativo do tapuia inassimilável e representando a si próprios com a figura amistosa, aberta aos cruzamentos e influências dos tupi.(...)Nesse final de década, os tempos se tornaram convulsos e as mentes se turvaram. 0 acirramento das militâncias queria ver em cada criatura um soldado, numa guerra que só admitia dois lados, o certo e o errado, o justo e o opressivo, o bem e o mal. As metáforas militares se tornam cumulativas, dominantes, sufocantes. Por toda parte se fala e se repete, exaustivas vezes, em frente única, combate, vitória, líder.

No entanto, alguns cronistas obscuros, jornalistas de ocasião ou escritores bissextos, nos deixaram uma outra visão acerca de todo esse embate entre nacionalismo e regionalismo. Esses autores vão ser denominados por Elias Thomé Saliba como sendo cronistas macarrônicos, pois seus escritos, do ponto de vista estilístico, eram marcados pela mistura, pelo fragmento, pelo caráter provisório e contingente, além do que acabaram por criar uma espécie de humor paulista, característico da belle époque. ${ }^{25}$

A mestiçagem idiomática nestes jornalistas de ocasião, a mistura de macarrônicos nos seus escritos, entre eles Juó Bananere, Cornélio Pires José Agudo, Agripino Grieco e outros, constituía ainda um recurso para fugir não apenas das fórmulas e ornatos da língua, mas do próprio idioma herdado, definido por um deles como "um insistente convite à incontinência da linguagem". Claro que havia as fortes características intrínsecas a uma produção cultural quase que inteiramente jornalística.

Rechaçando a identidade de uma cultura paulista, calcada ou num regionalismo pasteurizado ou num cosmopolitismo civilizador, esses macarrônicos acentuam os excessos da língua, as rebarbas do significado, incluindo os preconceitos sociais e os ressentimentos. Não possuíam respostas estéticas defini- 
das nem programáticas, não perfilavam difusa opção política, nem se congregavam em cortes ou igrejinhas; quase podemos vê-los como aqueles "literatas ambulantes" de que nos falava Brito Broca nas suas memórias.

Parece claro que Juó Bananére e seus compadres, com seu hibridismo sintático, sua mestiçagem idiomática, seu anarquismo lingüístico, sua linguagem truncada, tinha se tornado um pouco inconveniente naquela fábrica de nacionalismos, que era o clima mental vigente na São Paulo dos anos 20, quando os modernistas, entre outros, procuravam criar uma identidade simbólica para São Paulo.

O principal problema conceitual do historiador ao lidar com uma suposta tradição inventada é que ela parece incorporar aquela espécie de falsa consciência contra a qual haveria, por certo, uma versão mais adequada e, não raro, verdadeira. ${ }^{26}$

Não se trata disso aqui, a versão macarrônica da São Paulo da belle époque não traz nenhuma versão, porque afinal não queria nada e não pretendia ensinar nada. Talvez ela tenha sido, menos do que uma desinvenção da tradição, um corte inoportuno no tempo, uma epifania da emoção, abrindo apenas uma pequena vereda, uma brecha anárquica na narrativa triunfante. ${ }^{27}$

Uma das exceções não apenas pela utilização de processos lingüísticos similares aos macarrônicos, mas também por ter mantido uma atitude de sobriedade diante das discussões sobre o nacionalismo ao longo de todos os anos $20 \mathrm{e}$ sua posterior exacerbação no final da década, foi o escritor Antônio Alcântara Machado. Diante daquela situação, Alcântara Machado vai desabafar: “... eu berro contra essa tolice maníaca e inútil de numa investida querer saber quem é que marcha certo. Quem não escreve assim assado não é moderno brasileiro. Para ser considerado é preciso acomodar a sua maneira a uma bitola consagrada. Hoje se escreve brasileiro por sistema, por ser da moda". ${ }^{28}$

Na entrevista do ano de 1927, concedida a Peregrino Jr., de 0 Jornal, referese às divisões que começam a surgir dentro do grupo modernista:

Antigamente era a frente única. Pancada nos inimigos. Agora é a discórdia. Pancada nos companheiros. A preocupação de saber quem é que está certo. Ou o que é mais gostoso: quem é que está errado. Crítica e mais crítica. E principalmente a preocupação (idiota como já me disse Paulo Prado) de querer saber quem é de fato brasileiro da gema. A toda hora surge um cavalheiro batendo com a mão no peito: eu é que sou auriverde de verdade! $!^{29}$

Palavras que evidenciam a causa do debate: a questão nacionalista, da arte brasileira. Lembre-se de que a esta altura, além da corrente Pau-Brasil, tinha surgido a oposição Verde-amarelista. 
A descrença de Alcântara Machado diante da empresa modernista — que buscava a construção de uma identidade nacional redentora das contradições brasileiras - ecoava através da fina ironia do articulista.

0 pessimismo e o ceticismo do escritor diante do esperançoso parecem ter constituído matéria de artigos nos jornais e nos contos, nos quais já ressoa um princípio vital de sua obra, que é a irreverente ironia. Diante de um "projeto modernista" de construção da identidade nacional, Alcântara parece manter-se crítico à sua memória raquítica de ufanismo, desdenha a imagem idílica da nação. Sua lucidez irrequieta já não faz mais concessões. Zomba, cínico, do espírito de "brasileirismos de estandarte", eufórico geral, ironizando a mítica nacionalista modernista. Disseca, irônico, a idéia de identidade como míope e torta. A tão perseguida brasilidade revela-se, na perspectiva maliciosa do cronista, na realidade infestada de dissimulações e equívocos. Contra uma projetiva mística de recompor a brasilidade, a sua produção cultural propõe uma projetiva realista, marcada até as entranhas pela idéia de resgatar a experiência concreta dos indivíduos no dia a dia da contemporaneidade.

Na década de 20 observa-se a prolongação do debate ideológico no campo cultural - a oposição recíproca entre o Modernismo de São Paulo e o regionalismo literário, e a conseqüente negação, da parte do primeiro, dos momentos constitutivos da sociedade tradicional, a célebre "trindade étnica", que o historicismo regionalista buscava valorizar.

Em dado momento essa atitude é praticamente unânime no grupo paulista. Oswald de Andrade fala da "metrópole cosmopolita" - evoluída de século em cinqüenta anos de "entradas" comovidas, onde se debatem, para amálgamas finais, canções de todos os idiomas, êxtases de todos os passados, generosidades e ímpetos de todas as migrações”, e Menotti del Picchia transmite a imagem grandiosa e apologética da cidade: São Paulo é hoje uma metrópole febril, milionária, impressionantemente enorme, onde "as emoções de todas as raças e tipos de todos os povos agitam uma das vidas sociais mais violentas e gloriosas do universo". E conclui, afirmando que "a raça brasileira" advirá do processo em que entram "todas as universais virtudes positivas dos povos imigrantes como a força de adaptação, ânsia de inédito, instinto de conquista. Essa, sim, será a raça brasileira. Talvez o único eco das anárquicas atitudes macarrônicas entre os modernistas triunfantes apareceu num texto obscuro e pouco conhecido de Manuel Bandeira, publicado em maio de 1924 e singularmente expurgado das obras completas do poeta. Contra o nacionalismo programático construtivista dos modernistas, Bandeira escreveu num desabafo de rara sinceridade:

A poesia brasileira vai entrar para a Liga Nacionalista. Oswald de Andrade acaba de deitar manifesto - uma espécie de plataforma-poema daquilo que ele chama 
Poesia Pau-Brasil. Eu protesto. 0 nome é comprido demais. Bastaria dizer poesia pau. Por inteiro: Manifesto Brasil da Poesia Pau. Porque é poesia de programa e toda a arte de programa é pau. Aborrecem os poetas que se lembram de nacionalidade quando fazem versos. Eu quero falar do que me der na cabeça. Quero ser eventualmente mistura de turco com sírio-libanês. Quero ter o direito de falar ainda na Grécia. Há pouco tempo entrei na Agência Havas no momento em que Américo Facó ditava pelo telefone um despacho recebido de Elêusis. Senti de pronto a ironia da emoção lírica. Não podia evidentemente falar de Tabatingüera $(\ldots)^{30}$

\section{NOTAS}

${ }^{1}$ DEL PICCHIA, Menotti. Na maré das reformas. Correio Paulistano, São Paulo, 24/1/1920.

${ }^{2}$ ANDRADE, Oswald de. Cadernos de poesia do aluno Oswald - (Poesias reunidas). São Paulo: Círculo do Livro, s/d., p.120.

${ }^{3}$ Ver BOSI, Alfredo. "O Brasil republicano, as letras e a primeira República”. In FAUSTO, Boris (org.). O Brasil republicano, sociedade e instituições. São Paulo: Difel, 1977, tomo III, vol.2, p.312.

$454{ }^{4}$ EDITORIAL "Nós - 0 Correio Paulistano por dentro". Correio Paulistano. São Paulo, 7/9/1922.

${ }^{5}$ ANDRADE, Mário de. "O movimento modernista”. Aspectos da literatura brasileira. São Paulo: Livraria Martins Editora, 1974, p.236.

${ }^{6}$ MELLO e SOUZA, Antônio Cândido de. Literatura e sociedade. São Paulo: Cia. Editora Nacional, 1965, p.189.

${ }^{7}$ MORAIS, Eduardo Jardim de. A brasilidade modernista, sua dimensão filosófica. Op. cit., p.87.

${ }^{8}$ ANDRADE, Mário de. "Carta Protesto". Terra roxa e outras terras. nํ 2, p.4. Apud: MORAIS, Eduardo Jardim de. A brasilidade modernista, sua dimensão filosófica. Op. cit., pp.106-7.

${ }^{9}$ Idem,. p.107.

${ }^{10}$ LOPEZ, Telê Porto Ancona. Mário de Andrade: Ramais e caminho. São Paulo: Livraria Duas Cidades, 1972, p.215.

${ }^{11}$ ANDRADE, Mário de. "Oswald de Andrade: Pau-Brasil”, set. 1925 (originais datilografados de M. de A. - IEB-USP). Apud: LOPEZ, Telê Porto Ancona. Mário de Andrade: Ramais e caminho, op. cit., p. 216.

${ }^{12}$ ANDRADE, Mário de. "Música Brasileira". A Manhã. São Paulo, 24/3/1926. (Suplemento de recortes de escritos do autor. IEB-USP). Apud: LOPEZ, Telê Porto Ancona. Mário de Andrade: Ramais e caminho, op. cit., p.218.

${ }^{13}$ ANDRADE, Mário de. Poesias Completas. São Paulo: Círculo do Livro, 1976, pp.57-8. 
${ }^{14}$ Idem, p.60.

${ }^{15}$ Idem, pp.49-50.

${ }^{16}$ Idem, p.242.

${ }^{17}$ Idem, pp.247-8.

${ }^{18}$ Idem, p.299.

${ }^{19}$ Idem, pp.45-7.

${ }^{20}$ Idem, pp. 56-7.

${ }^{21}$ Idem, p.63.

${ }^{22}$ ANDRADE, Mário de. Aspectos da literatura brasileira, op. cit., p. 244.

${ }^{23}$ ANDRADE, Carlos Drummond de. "Prefácio". In CARDOZO, Joaquim. Poemas. Rio de Janeiro: Livraria Agir Editora, 1948, p.7.

${ }^{24}$ ANDRADE, Mário de. Poesias Completas. Op. cit., pp. 151-165.

${ }^{25}$ SALIBA, Elias Thomé. "Bananéres, briguelas e brodos: fragmentos do humor paulista na 1a República." São Paulo: novas fontes, abordagens e temáticas, nº 5. São Paulo: Museu Paulista da Universidade de São Paulo, jan./dez.1996. (Cadernos de História de São Paulo), p.32.

${ }^{26}$ Por tradição inventada entende-se um conjunto de práticas de natureza ritual ou simbólica, que visa a inculcar certos valores através da repetição, o que implica, automaticamente, uma continuidade em relação ao passado. Conf. HOBSBAWN, Eric J. e RANGER, Terence (orgs.). A invenção das tradições. Rio de Janeiro: Paz e Terra, 1984 (trad: Helena C. Cavalcante).

${ }^{27}$ SALIBA, Elias Thomé. Op. cit., p.38.

${ }^{28}$ ALCÂNTARA MACHADO, Antônio de. Prosa preparatória \& cavaquinho e saxofone, p.281. Apud: SEVCENKO, Nicolau. Orfeu extático na metrópole-São Paulo sociedade e cultura nos frementes anos 20, op. cit., p. 300. Nicolau Sevcenko aponta a figura de Sérgio Buarque de Holanda, já naquele momento uma das mentes que fugiram dos engajamentos maniqueístas, das "plataformas" e "programas", de todos os "idealismos fáceis", como colocava o seu amigo Prudente de Morais Neto.

${ }^{29}$ Artigo de ALCÂNTARA MACHADO, Antônio de. O Jornal. Rio de Janeiro, 12.2.1927.

${ }^{30}$ BANDEIRA, Manuel. “O mundo literário”. Apud: SALIBA, Elias Thomé. "Bananéres, briguelas e brodos: fragmentos do humor paulista na $1^{\text {a }}$ República”, op. cit., p. 37.

Artigo recebido em 04/2000. Aprovado em 10/2000. 